\title{
ANALISIS TINGKAT KEPUASAN MAHASISWA TERHADAP KINERJA DOSEN SEKOLAH TINGGI ILMU EKONOMI (STIE) DIWILAYAH KOTA PEKANBARU
}

\author{
Elida Gultom ${ }^{1}$ Nurhayana $^{2}$ \\ Sekolah Tinggi Ilmu Ekonomi Riau (STIER) \\ Jln. HR. Subrantas 57 KM 12 Panam Pekanbaru 28293 Telp. (0761) 63237 \\ E-mail : gultom_elida@yahoo.com
}

\begin{abstract}
This study aims to find out how the level of student satisfaction on the performance of lecturers of the College of Economics (STIE) in the city of Pekanbaru. The population in this study were all students who were still active in lectures at the College of Economics in the city of Pekanbaru which consisted of 7 (seven) campuses of the College of Economics (STIE) with a total of 7,367 students. While the sample was taken as many as 500 respondents with sampling techniques using quota sampling and data analysis techniques used were descriptive analysis methods. Based on the results of the study, it was found that the level of student satisfaction on the performance of lecturers of the Economics College in the city of Pekanbaru, in terms of the pedagogic competence of the majority of $63.5 \%$ respondents expressed satisfaction with aspects of pedagogic competence. Judging from professional competence most of the respondents $62.3 \%$ expressed satisfaction with the aspect of professional competence. Judging from the personality competencies, most respondents $63.7 \%$ expressed satisfaction with the aspect of personality competence. And in terms of social competence most of the respondents, namely $59.80 \%$ expressed satisfaction with as pects of social competence.
\end{abstract}

Keywords: Student Satisfaction; Lecturer Performance

Meningkatnya kesadaran masyarakat kota pekanbaru khususnya dan provinsi Riau pada umumnya terhadap pentingnya memiliki pendidikan tinggi formal, menjadikan Sekolah Tinggi Ilmu Ekonomi (STIE) menjadi salah satu yang perguruan tinggi yang cukup diminati oleh calon mahasiswa untuk tempat menimba ilmu. Adapun salah satu alasan mahasiswa memilih STIE tempat kuliah adalah bisa bekerja sambil kuliah. Dimana jam belajar ada yang dilakukan di malam hari sehingga tidak mengganggu jam kerja. Hal ini juga bisa dilihat dari banyaknya jumlah Sekolah Tinggi Ilmu Ekonomi (STIE) yang ada di wilayah Kota Pekanbaru. Pada tahun 2017 terdapat 7 (tujuh) kampus STIE dengan memiliki 2 (dua) program studi yaitu akuntansi dan manajemen yang tercatat di kopertis $X$. Banyaknya kampus STIE tersebut menimbulkan persaingan yang cukup kompetitif diantara kampus STIE tersebut, yang berakibat terhadap lembaga pendidikan untuk memperhatikan mutu pendidikan dan kelembagaan Sekolah Tinggi Ilmu Ekonomi
(STIE) supaya mampu serta unggul dalam persaingan tersebut.

Berikut perkembangan jumlah mahasiswa 5 tahun terakhir pada masingmasing kampus STIE yang berada diwilayah kota Pekanbaru.

Tabel 1. Perkembangan jumlah mahasiswa pada Sekolah TInggi Ilmu Ekonomi di Wilayah Kota Pekanbaru Tahun 2012-2016

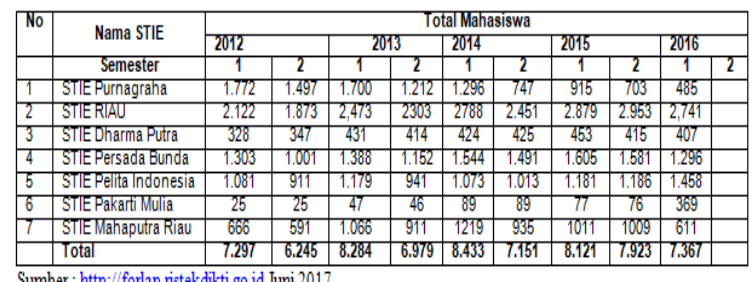

Berdasarkan tabel 1 diatas, dapat memberikan informasi bahwa jumlah mahasiswa secara keseluruhan dalam waktu tahun 2012 hingga tahun 2016 di semester kedua terus mengalami kenaikan dan terdapat persaingan yang ketat diantara kampus STIE yang berada di wilayah Pekanbaru. 
(STIE) di wilayah Kota Pekanbaru (Elida Gultom; Nurhayana)

Berikut grafik jumlah mahasiswa tahun 2016 semester 1 pada masing masing Kampus STIE di wilayah kota Pekanbaru.

Jumlah Mahasiswa

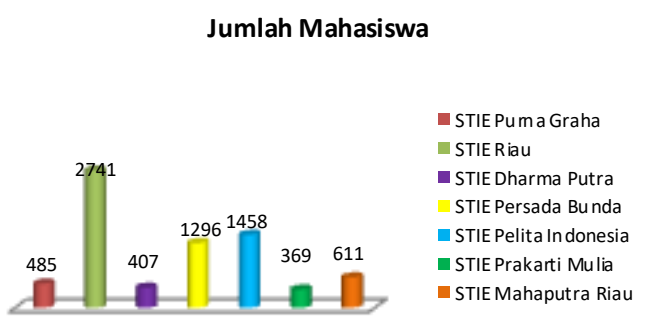

Grafik diatas menjelaskan bahwa, STIE Purnagraha memiliki mahasiswa sebanyak 485 orang, STIE Riau sebesar 2.741 mahasiswa, STIE Dharma Putra sebesar 407, mahasiswa STIE Persada Bunda sebesar 1.296, mahasiswa STIE Pelita Indonesia sebesar 1.458 mahasiswa, jumlah mahasiswa STIE Pakarti Mulia sebesar 369 mahasiswa dan jumlah mahasiswa pada STIE Mahaputra Riau sebesar 611 mahasiswa.

Mahasiswa merupakan konsumen /pelanggan dari suatu lembaga pendidikan tinggi (universitas) sedangkan kinerja dosen merupakan ujung tombak penyelenggara pendidikan dan pengajaran. Dosen merupakan orang yang paling erat hubungannya dengan prestasi belajar mahasiswa yang akan mempengaruhi tingkat kepuasan mahasiswa. Seperti yang disampaikan oleh Indrajit (2006) bahwa "Kinerja dosen Merupakan salah satu ujung tombak yang menentukan kesuksesan di perguruan tinggi. Oleh karena itu pengembangan dan pengukuran kinerja dosen sangatlah penting untuk dilakukan.

Berikut tabel jumlah dosen tetap dan jumlah dosen tidak tetap pada Sekolah Tinggi Ilmu Ekonomi di Wilayah Kota Pekanbaru.

Tabel 2. Jumlah Dosen STIE di Wilayah Kota Pekanbaru

\begin{tabular}{|l|l|c|c|c|}
\hline No & STIE & $\begin{array}{c}\text { Dosen } \\
\text { Tetap }\end{array}$ & $\begin{array}{c}\text { Dosen } \\
\text { Tidak } \\
\text { Tetap }\end{array}$ & Total \\
\hline 1 & STIE RIAU & 50 & 0 & 50 \\
\hline 2 & STIE Dharma Putra & 16 & 0 & 16 \\
\hline 3 & STIE Persada Bunda & 50 & 0 & 50 \\
\hline 4 & STIE Pelita Indonesia & 53 & 0 & 53 \\
\hline 5 & STIE Purna Graha & 26 & 1 & 27 \\
\hline 6 & STIE Mahaputra Riau & 26 & 1 & 27 \\
\hline
\end{tabular}

\begin{tabular}{|l|l|c|c|c|}
\hline 7 & STIE Prakarti & 14 & 2 & 16 \\
\hline Jumlah & 235 & 4 & 239 \\
\hline
\end{tabular}

Sumber : http://forlap.ristekdikti.go.id Juni, 2017

Berdasarkan tabel 2 diatas, jumlah dosen pada Sekolah Tinggi Ilmu Ekonomi di wilayah Kota Pekanbaru sebanyak 239 orang dimana, jumlah dosen tetap sebesar 235 orang dan jumlah dosen tidak tetap sebanyak 4 orang. Menurut Simonson dalam Husnayetti (2012), agar dapat memenangkan persaingan perlu memenuhi apa yang diinginkan oleh mahasiswa. Terciptanya kepuasan mahasiswa melalui proses belajar mengajar dapat merupakan promosi tanpa mengeluarkan biaya karena mahasiswa yang merasa puas tersebut akan menyampaikan kepada rekan-rekannya yang lain untuk memilih tempat kuliah. Dengan kata lain mahasiswa tersebut membentuk rekomendasi dari mulut ke mulut (word of mouth) yang dapat menguntungkan lembaga (Tjiptono, 1997:24). Peluang meningkatnya kepuasan tersebut dapat memberikan pengaruh yang hebat dalam lembaga.

Berbagai fenomena yang telah dipaparkan diatas menimbulkan pertanyaan yang penting untuk dijawab melalui suatu penelitian empiris. Keterkaitan kinerja dosen dengan kepuasan mahasiswa yang pada gilirannya akan berdampak pada mutu pendidikan karena meningkatnya kualitas mengajar dosen pada STIE di Wilayah Kota Pekanbaru akan mempengaruhi kepuasan mahasiswa..

Penelitian mengenai kepuasan mahasiswa terhadap kinerja dosen sudah banyak dilakukan, beberapa diantaranya sebagai berikut: Maria Ulfa (2012) dengan judul Analisis Tingkat Kepuasan Mahasiswa Terhadap Kinerja Dosen dalam Pembelajaran Pada Program Studi Pendidikan Ekonomi Universitas Riau. Suarman (2015) yang berjudul Teaching Quality and Students Satisfaction: The Intermediatory Role of Relationship between Lecturers and Students of the Higher Learning Institutes. Kemudian penelitian yang berjudul Mengukur 
Kepuasan Mahasiswa Berdasarkan Kinerja Dosen dalam Proses Perkuliahan (Studi Empiris di Universitas Muhammadiyah Purwokerto) yang ditulis oleh Suyoto dan Agung Miftahudin (2014) penelitian yang dilakukan oleh Jian Xiao dan Stephen Wilkins (2015), dengan judul The Effects of Lecturer Commitment on Student Perceptions of Teaching Quality and Student Satisfaction in Chinese Higher Education.

Berangkat dari penelitian-pelitian terdahulu yang telah dipaparkan diatas, peneliti tertarik untuk melakukan penelitian ini akan menganalisis tingkat kepuasan mahasiswa terhadap kinerja dosen pada Sekolah Tinggi Ilmu Ekonomi di wilayah Kota Pekanbaru. kepuasan mahasiswa terhadap kinerja dosen pada Sekolah Tinggi Ilmu Ekonomi di wilayah Kota Pekanbaru.

Menurut Rivai dan Ella (2011:548), pengertian kinerja adalah prestasi kerja karyawan yang ditunjukkan melalui perilaku nyata sesuai dengan peranannya di dalam perusahaan.Sedangkan menurut Kasmir (2016:182) pengertian kinerja adalah hasil kerja dan perilaku kerja yang dicapai oleh karyawan dalam satu periode tertentu dalam menyelesaikan tugas-tugas dan tanggungjawab yang diberikan oleh organisasi/perusahaan.

Menurut Kasmir (2016:189), Ada beberapa faktor-faktor yang mempengaruhi kinerja yaitu sebagai berikut : Kemampuan dan keahlian, Rancangan kerja, Motivasi kerja Kepemimpinan, Gaya kepemimpinan, Budaya Organisasi, Kepuasan Kerja, Lingkungan Kerja, Loyalitas, Komitmen dan Disiplin Kerja

\section{METODE}

\footnotetext{
Penelitian ini menggunakan metode analisis deskriptif presentase dengan langkah langkah sebagai berikut: Skoring yaitu memberikan skor terhadap butir-butir pertanyaan yang terdapat dalam angket, Pada penskoran ini, langkah yang ditempuh adalah memasukkan data-data angket yang telah diperoleh kemudian menjumlahkan masingmasing jawaban yang diberikan responden
}

dalam angket penelitian dan Tabulasi dan analisis yaitu perhitungan data yang sudah diberikan skor berdasarkan jenis data yang dikumpulkan yaitu data kualitatif yang kemudian diubah menjadi kuantitatif, maka teknik yang digunakan adalah analisis statistik, yaitu dengan menggunakan rumus statistik (persentase) yang digunakan untuk mendeskripsikan hasil penelitian dengan menggunakanrumus sebagai berikut :

$$
P=\frac{F}{N} \times 100
$$

$$
\begin{aligned}
& \text { Keterangan : } \\
& \mathrm{P}=\text { Angket Persentase } \\
& \mathrm{F}=\text { Frekuensi Jawaban } \\
& \mathrm{N}=\text { Banyaknya Responden }
\end{aligned}
$$

\section{HASIL}

Demografi responden terdiri dari jenis kelamin dan usia responden. Berdasarkan hasil penelitian, diperoleh responden yang berjenis kelamin laki-laki sebanyak $223(44,6 \%)$ responden dan responden yang berjenis kelamin perempuan sebanyak $277(55,4 \%)$. Berikut grafik jenis kelamin responden pada tingkat kepuasan mahasiswa terhadap kinerja dosen STIE di wilayah kota Pekanbaru.

Gambar 3.Responden Berdasarkan Jenis Kelamin

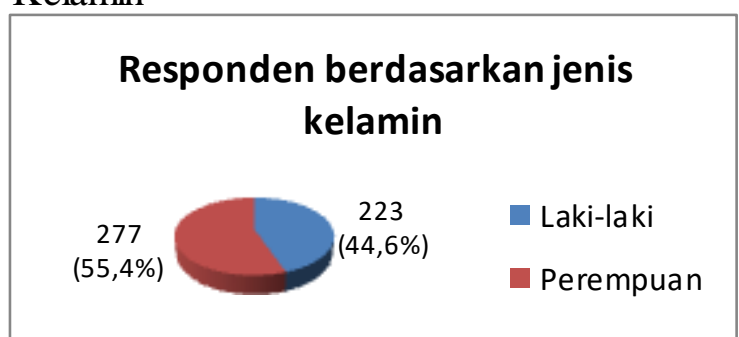

Berdasarkan usia responden pada Mahasiswa Sekolah Tinggi Ilmu Ekonomi di Wilayah Kota Pekanbaru, dapat diketahui bahwa responden yang berusia antara 18 tahun sampai 21 tahun sebanyak 161 $(32,2 \%)$ responden, usia antara 22 sampai 25 tahun sebanyak 270 (54\%) responden, usia antara 26 sampai 29 tahun sebanyak 40 (8\%) responden, usia antara 30 sampai 33 tahun sebanyak $16(3,2 \%)$ responden dan usia diatas 34 tahun sebanyak $13(2,6 \%)$ 
(STIE) di wilayah Kota Pekanbaru (Elida Gultom; Nurhayana)

responden.

Gambar 4. Responden Berdasarkan Usia

\section{Responden Berdasarkan Usia}

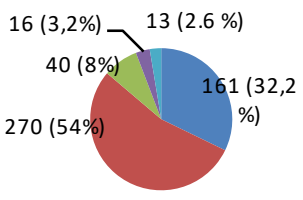

$18-21$

$22-25$

$26-29$

- $30-33$

\begin{tabular}{cll}
\multicolumn{2}{c}{ Berdasarkan hasil tanggapan } \\
responden tentang tingkat kepuasan
\end{tabular} mahasiswa terhadap kinerja dosen Sekolah Tinggi Ilmu Ekonomi (STIE) di wilayah kota Pekanbaru, berikut ini disajikan hasil penelitian sebagai berikut:

Kompetensi Pedagogik. Kompetensi pedagogik merupakan kemampuan dosen dalam mengelola pembelajaran yang terdiri dari beberapa aspek antara lain: kesiapan memberika kuliah, (2) keteraturan dan ketertiban penyelenggaraan perkuliahan, (3) kemampuan menghidupkan suasana kelas, (4) kejelasan penyampaian materi, (5) pemanfaatan media dan teknologi pembelajaran, (6) cara pengukuran hasil belajar, (7) umpan balik terhadap tugas (8) kesesuaian materi ujian dan tugas dengan tujuan materi kuliah dan (9) Kesesuaian nilai yang diberikan dengan hasil belajar.

Tabel 4 Distribusi Frekuensi kepuasan mahasiswa terhadap kinerja dosen

\begin{tabular}{|c|c|c|c|c|c|c|c|c|}
\hline \multirow{2}{*}{$\frac{N_{0}}{\mathrm{a}}$} & Aspek & \multicolumn{7}{|c|}{ Penilaian } \\
\hline & Kompetensi Pedagogik & SP & $P$ & $\mathrm{KP}$ & TP & STP & $\Sigma$ & Mean \\
\hline 1 & Kesiapan memberikan kuliah & $\frac{(5)}{104}$ & (4) & $\frac{(3)}{26}$ & $\frac{(2)}{0}$ & (1) & 500 & 416 \\
\hline 2 & Keteraturan dan ketertiban & 95 & 336 & 60 & 8 & 1 & 500 & 4.03 \\
\hline 3 & Kemampuan menghidupkan suasana & 104 & 291 & 96 & 9 & 0 & 500 & 3.98 \\
\hline 4 & $\begin{array}{l}\text { Kejelasan penyampaian materi } \\
\text { jawaban terhadapp pertanyaan di kelas }\end{array}$ & 107 & 322 & 70 & 1 & 0 & 500 & 4.07 \\
\hline 5 & $\begin{array}{l}\text { Pemanfaatan media dan telnologi } \\
\text { pembelaiaran }\end{array}$ & 83 & 265 & 121 & 25 & 6 & 500 & 3.79 \\
\hline 6 & $\begin{array}{l}\text { Keanekaragaman cara pengukuran } \\
\text { hasil belajar. }\end{array}$ & 77 & 328 & 90 & 5 & 0 & 500 & 3.95 \\
\hline 7 & $\begin{array}{l}\text { Pesumberian umpan balik terhadap } \\
\text { Pugas. }\end{array}$ & 100 & 329 & 65 & 6 & 0 & 500 & 4.05 \\
\hline 8 & $\begin{array}{l}\text { Kesesuain materi ujian dan tugas } \\
\text { dengan tujuan mata kuliah. }\end{array}$ & 137 & 310 & 49 & 3 & 1 & 500 & 4.16 \\
\hline 9 & $\begin{array}{l}\text { Kesesuaian nilai yang diberikan } \\
\text { dengan hasil belajar }\end{array}$ & 131 & 305 & 58 & 6 & 9 & 500 & 4.12 \\
\hline & Rata-Rata (\%) & 20.8 & 63.5 & 14.1 & 1.4 & 0.2 & 500 & 4.03 \\
\hline
\end{tabular}

Berdasarkan tabel 4.1 diatas dapat diketahui bahwa dari keseluruhan instrumen pada dimensi kompetensi pedagogik diperoleh $63,5 \%$ responden menyatakan merasa puas terhadap kinerja dosen pada kompetensi pedagogik. 20,8\% merasa sangat puas, $14,1 \%$ merasa kurang puas dan hanya $1,4 \%$ yang merasa tidak puas serta $0,2 \%$ merasa sangat tidak puas.

\section{Kompetensi}

Profesional, Kompetensi profesional adalah kemampuan penguasaan materi pelajaran secara luas dan mendalam yang meliputi : kemampuan menjelaskan pokok bahasan topik secara tepat, kemampuan memberi contoh relevan dan konsep yang diajarkan, kemampuan menjelaskan keterkaitan topik yang diajarkan dengan konteks kehidupan, penguasaan akan isu-isu mutakhir dalam bidang yang diajarkan, penggunaan hasilhasil penelitian untuk meningkatkan kualitas perkuliahan, pelibatan mahasiswa dalam penelitian dan kemampuan menggunakan beragam teknologi komunikasi.

Tabel 5. Distribusi Frekuensi Kepuasan Mahasiswa Terhadap Kinerja Dosen Pada

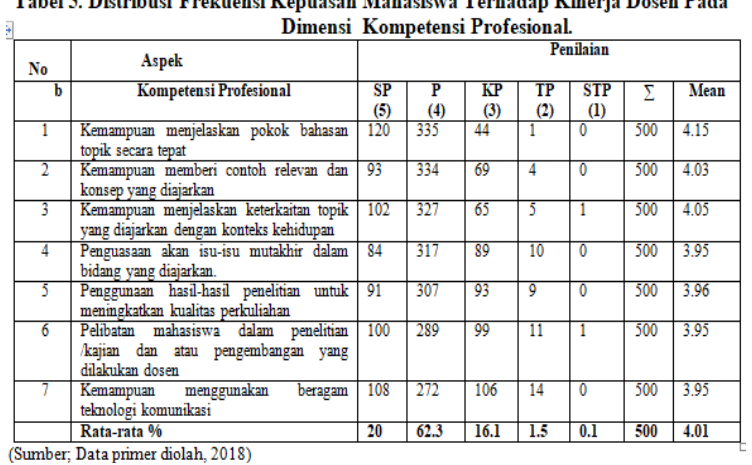

Berdasarkan tabel 5 diatas dapat diketahui bahwa dari keseluruhan instrumen pada dimensi kompetensi profesional diperoleh 62,3 \% responden menyatakan merasa puas terhadap kinerja dosen pada kompetensi profesional. 20\% merasa sangat puas, 16,1 \% merasa kurang puas dan hanya $1,4 \%$ yang merasa tidak puas serta $0,2 \%$ merasa sangat tidak puas.

Kompetensi Kepribadian, Dosen sebagai tenaga pendidik yang tugas utamanya mengajar, memiliki

karakteristik kepribadian yang sangat berpengaruh terhadap keberhasilan pengembangan sumber daya manusia. Kepribadian yang baik dari seorang dosen akan memberikan teladan yang baik terhadap mahasiswa maupun masyarakat. Kompetensi kepribadian mencakup: kewibawaan sebagai pribadi dosen, kearifan dalam mengambil keputusan, menjadi contoh dalam berprilaku, sesuai kata dan tindakan, kemampuan mengendalikan diri dan adil dalam memperlakukan mahasiswa. 
(STIE) di wilayah Kota Pekanbaru (Elida Gultom; Nurhayana)

Tabel 6 Distribusi Frekuensi Kepuasan Mahasiswa Terhadap Kinerja Dosen Pada Dimensi Kompetensi Kepribadian.

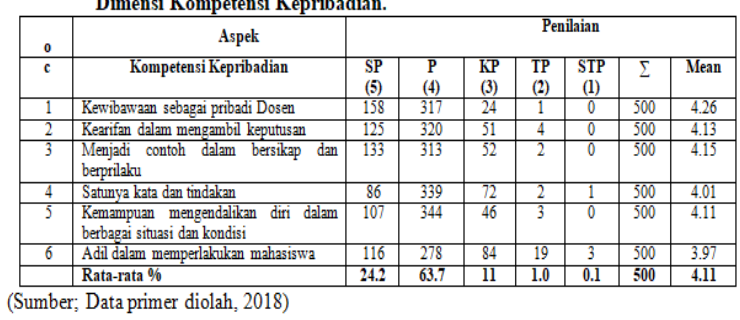

Berdasarkan tabel 6 diatas dapat diketahui bahwa dari keseluruhan aspek pada dimensi kompetensi kepribadian diperoleh $63,7 \%$ responden menyatakan merasa puas terhadap kinerja dosen dimensi kompetensi pedagogik. $24,2 \%$ merasa sangat puas, $11 \%$ merasa cukup puas dan hanya $1 \%$ yang merasa tidak puas, serta $0,1 \%$ merasa sangat tidak puas.

Kompetensi sosial merupakan kemampuan dosen untuk berkomunikasi dan berinteraksi secara efektif dan efisien dengan peserta didik, sesama dosen, orangtua/wali peserta didk dan masyarakat sekitar. Kompetensi sosial meliputi aspek yang terdiri dari kemampuan menyampaikan pendapat, kemampuan menerima kritik dan saran serta pendapat dari orang lain, mengenal dengan baik mahasiswa yang mengikuti kuliahnya, mudah bergaul dikalangan sejawat, karyawan dan mahasiswa serta memiliki toleransi terhadap keberagaman mahasiswa.

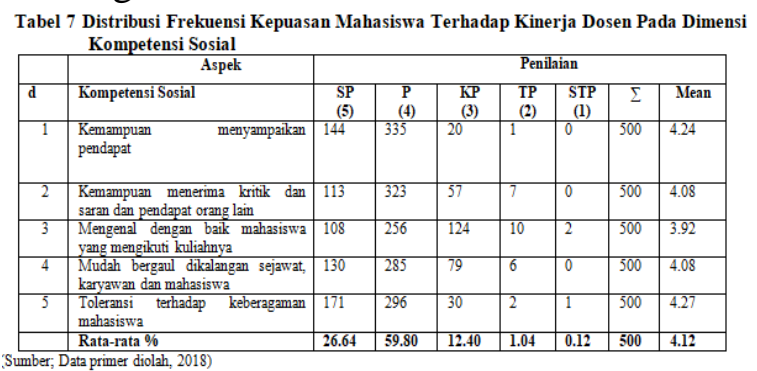

Berdasarkan tabel 7 diatas dapat diketahui bahwa dari keseluruhan aspek pada dimensi kompetensi sosial diperoleh 59,80\% responden menyatakan merasa puas terhadap kinerja dosen dimensi kompetensi sosial. $26,64 \%$ merasa sangat puas, $12,40 \%$ merasa kurang puas dan hanya $1,04 \%$ yang merasa tidak puas, serta $0,12 \%$ merasa sangat tidak puas.

Tabel 8 Distribusi Frekuensi Kepuasan Mahasiswa Terhadap Kinerja Dosen

\begin{tabular}{|c|c|c|c|c|c|c|c|c|}
\hline O & \multirow[b]{2}{*}{ Variabel } & \multicolumn{7}{|c|}{ Penilaian/Rata-rata Persentasi } \\
\hline $\mathrm{N}$ & & $\begin{array}{l}\text { SP } \\
(5)\end{array}$ & $\begin{array}{l}P \\
\text { (4) }\end{array}$ & $\begin{array}{l}K P \\
(3)\end{array}$ & $\begin{array}{l}\text { SPT } \\
\text { (2) }\end{array}$ & $\begin{array}{l}\text { SPT } \\
\text { (1) }\end{array}$ & $\varepsilon$ & Mean \\
\hline 1 & Kompetensi Pedagogik & 20.8 & 63.5 & 14.1 & 1.4 & 0.2 & 500 & 4.03 \\
\hline 2 & Kompetensi Profesional & 20 & 62.3 & 16.1 & 1.5 & 0.1 & 500 & 4.01 \\
\hline 3 & Kompetensi Kepribadian & 24.2 & 63.7 & 11 & 1.0 & 0.1 & 500 & 4.11 \\
\hline 4 & Kompetenni Sosial & 26.6 & 59.8 & 12.4 & 1.0 & 0.1 & 500 & 4.12 \\
\hline
\end{tabular}

(Sumber; Data primer diolah, 2018)

Berdasarkan tabel 8. diatas dapat diketahui bahwa dari keseluruhan aspek rata rata kepuasan reponden pada variabel kompetensi pedagogik rata rata persentase sebesar $63,5 \%$ dengan mean 4,03. Pada variabel kompetensi professional, rata-rata persentase kepuasan responden sebesar 63,7 $\%$ dengan mean 4,01. Rata-rata persentase kepuasan responden pada kompetensi kepribadian sebesar $63,7 \%$ dengan mean 4,11, sedangkan rata-rata persentase kepuasan responden terhadap kinerja dosen pada kompetensi social sebesar 59,8\% dengan mean 4,12

\section{PEMBAHASAN}

Kinerja dosen merupakan perilaku nyata yang ditampilkan setiap dosen sebagai prestasi yang dihasilkan oleh dosen tersebut dalam menyelesaikan tugas-tugas dan tanggungjawab yang diberikan dalam satu periode tertentu.

Hasil analisis pada variabel kompetensi pedagogik diperoleh rata-rata kepuasan responden sebesar 63,5\%. Hal ini menunjukkan bahwa persiapan dosen dalam menyiapkan materi kuliah, ketertiban dalam perkuliahan, kemampuan dalam menghidupkan suasana di kelas, penyampaian materi yang jelas, kesesuaian materi ujian dan tugas dengan tujuan materi kuliah dan kesesuaian nilai yang diberikan dengan hasil belajar, pemanfaatan media dan teknologi pembelajaran, cara pengukuran hasil belajar, dan umpan balik terhadap tugas sudah terlaksana dengan baik, namun demikian masih ada mahasiswa yang merasakan kurang puas bahkan sangat tidak puas terhadap kompetensi pedagogik dosen. pada Sekolah Tinggi Ilmu Ekonomi di wilayah Kota Pekanbaru artinya kinerja dosen masih 
(STIE) di wilayah Kota Pekanbaru (Elida Gultom; Nurhayana)

perlu ditingkatkan yang berkaitan dengan kesembilan aspek diatas terutama aspek dalam pemanfaatan media dan teknologi pembelajaran, keanekaragaman dalam pengukuran hasil belajar serta kemampuan menghidupkan suasa kelas.

Pada variabel kompetensi profesional diperoleh $62,3 \%$ responden menyatakan merasa puas terhadap kinerja dosen pada kompetensi professional. Hal ini berarti bahwa kemampuan dosen dalam menjelaskan pokok bahasan topik secara tepat, kemampuan memberi contoh relevan dan konsep yang diajarkan, kemampuan menjelaskan keterkaitan topik yang diajarkan dengan konteks kehidupan, penguasaan akan isu-isu mutakhir dalam bidang yang diajarkan, penggunaan hasil-hasil penelitian untuk meningkatkan kualitas perkuliahan, pelibatan mahasiswa dalam penelitian dan kemampuan menggunakan beragam teknologi komunikasi sudah berjalan dengan baik, namun demikian karena masih temukannya mahasiswa yang merasa kurang puas dan bahkan sangat tidak puas pada dimensi kompetensi profesional ini maka kepada dosen Sekolah Tinggi Ilmu Ekonomi di wilayah Kota Pekanbaru masih harus meningkatkan kompetensi profesionalnya yang berkaitan dengan ketujuh aspek diatas terutama dalam Pelibatan mahasiswa dalam penelitian /kajian dan atau pengembangan yang dilakukan dosen dan Penguasaan akan isu-isu mutakhir dalam bidang yang diajarkan serta Penggunaan hasil-hasil penelitian untuk meningkatkan kualitas perkuliahan.

Pada variabel kompetensi kepribadian diperoleh $63,7 \%$ responden menyatakan merasa puas terhadap kinerja dosen. Hal ini berarti bahwa secara umum dosen sudah memiliki kepribadian yang baik. Namun demikian, karena masih ada mahasiswa yang kurang puas bahkan sangat tidak puas terhadap kompetensi kepribadian dosen Sekolah Tinggi Ilmu Ekonomi di wilayah kota Pekanbaru maka masih perlu ditingkatkan dengan keenam instrumen diatas terutama dalam aspek adil dalam memperlakukan mahasiswa, serta satunya kata dan tindakan.
Pada variabel kompetensi sosial diperoleh $59,80 \%$ responden menyatakan merasa puas terhadap kinerja dosen. Hal ini berarti bahwa kemampuan dosen dalam menyampaikan pendapat, kemampuan menerima kritik dan saran serta pendapat dari orang lain, mengenal dengan baik mahasiswa yang mengikuti kuliahnya, mudah bergaul dikalangan sejawat, karyawan dan mahasiswa serta memiliki toleransi terhadap keberagaman mahasiswa sudan terlaksana dengan baik. Namun demikian, karena masih ada mahasiswa yang kurang puas bahkan sangat tidak puas terhadap kompetensi sosial dosen Sekolah Tinggi Ilmu Ekonomi di wilayah kota Pekanbaru maka masih perlu ditingkatkan dengan kelima aspek diatas terutama dalam aspek mengenal dengan baik mahasiswa yang mengikuti kuliahnya.

\section{SIMPULAN}

Berdasarkan hasil analisis data dan pembahasan yang telah diuraikan pada bab sebelumnya, maka hasil penelitan tentang analisis tingkat kepuasan mahasiswa terhadap kinerja dosen Sekolah Tinggi Ilmu Ekonomi di wilayah kota Pekanbaru diambil kesimpulan sebagai berikut :

1. Tingkat kepuasan mahasiswa terhadap kinerja dosen Sekolah Tinggi Ilmu Ekonomi di wilayah kota Pekanbaru yang ditinjau dari kompetensi pedagogik adalah sebagian besar responden yaitu 63,5\% menyatakan puas terhadap aspek dimensi kompetensi pedagogik.

2. Tingkat kepuasan mahasiswa terhadap kinerja dosen Sekolah Tinggi Ilmu Ekonomi di wilayah kota Pekanbaru yang ditinjau dari kompetensi profesional adalah sebagian besar responden yaitu 62,3\% menyatakan puas terhadap aspek dimensi kompetensi profesional.

3. Tingkat kepuasan mahasiswa terhadap kinerja dosen Sekolah Tinggi Ilmu Ekonomi di wilayah kota Pekanbaru yang ditinjau dari kompetensi kepribadian adalah sebagian besar responden yaitu $63,7 \%$ menyatakan 
puas terhadap aspek dimensi kompetensi kepribadian.

4. Tingkat kepuasan mahasiswa terhadap kinerja dosen Sekolah Tinggi Ilmu Ekonomi di wilayah kota Pekanbaru yang ditinjau dari kompetensi sosial adalah sebagian besar responden yaitu 59,80\% menyatakan puas terhadap aspek dimensi kompetensi sosial.

\section{DAFTAR RUJUKAN}

Daryanto dan Ismanto Setyobudi.2014. Konsumen dan Pelayanan Prima.Gava Media, Yogyakarta.

Husnayetti 2012. Tingkat Kepuasan Mahasiswa dan Proses Belajar Mengajar Di Perguruan Tinggi X. Volume 1, No 2. Halaman 115 124.

Hasan, Ali. 2013. Marketing dan KasusKasus Pilihan. CAPS. Yogyakarta.

Indrajit dan Djokopranoto.2006. Manajemen Perguruan Tinggi Modern. Andi Offset. Yogyakarta.

Kasmir. 2016. Manajemen Sumber Daya Manusia (Teori dan Praktek). RajaGrafindo Persada. Jakarta.

Kotler,P dan Keller.K.L .2007. Manajemen Pemasaran, Edisi Keduabelas, Jilid I, Edisi Bahasa Inggris. Pearson Education, Inc. Upper Saddler River, New Jersey, 07458, Edisi Bahasa Indonesia, PT Indeks.

Majid,Abdul.2005. Perencanaan Pembelajaran: Mengembangkan Standar Kompetensi Guru. PT Remaja Rosdakarya. Bandung.

Muhaimin.2004. Paradigma Pendidikan Islam. PT. Remaja Rosdakarya: Bandung

Muzenda, Allexander. 2013. Lecturers' Competences and Students' Academic Performance. International Journal of Humanities and Social Science Invention. Volume 3 Issue 1/ January. Page 0613.

Ruslan. 2010. Kepuasan Mahasiswa Terhadap Kinerja Dosen. Jurnal Ilmu Pendidikan Jilid 17 No 3. Halaman 230-237.
Rivai Veithzal \& Ella Jauvani Sagala (2011), Manajemen Sumber Daya Manusia Untuk Perusahaan Dari Teori Ke Praktik, Cetakan Ke-4, Rajawali Pers, Jakarta.

Suarman.2015.Teaching Quality and Students Satisfaction: The Intermediatory Role of Relationship between Lecturers and Students of the Higher Learning Institutes. Mediterranean Journal of Social Sciences. Volume 6 No. 2 Page 626-632.

Suyoto dan Agung Miftahudin. 2014. Mengukur Kepuasan Mahasiswa Berdasarkan Kinerja Dosen Dalam Proses Perkuliahan (Studi Empiris diUniversitas Muhammadiyah Purwokerto).Volume XI No 2 . Halaman 37-55.

Sugiyono. 2013. Metode Penelitia Bisnis. Alfabeta.Bandung.

Sukmanasa, Novita, Sundari. 2017. Analisis

Kepuasan Mahasiswa Terhadap

Kinerja Dosen Program Studi Guru Sekolah Dasar Universitas Pakuan. Jurnal Ilmiah Pendidikan 'Pedagonal'Volume 1 Nomor 2 Hal.91-99.

Sulastri, Tuti.2016. Analisis Kepuasan Mahasiswa Terhadap Kinerja Dosen. Jurnal Ilmiah Ekonomi Manajemen dan Kewirausahaan "Optimal' Volume 10 Nomor 2. Hal. 167-184.

Tjiptono, Fandy.2008. Service Management, Mewujudkan Layanan Prima. Andi. Yogyakarta

Ulfa, Maria. 2012. Analisis Tingkat Kepuasan Mahasiswa Terhadap Kinerja Dosen Dalam Pembelajaran Pada Program Studi Pendidikan Ekonomi Universitas Riau. Pekanbaru

Undang-Undang No 14 Tahun 2005

Tentang Guru dan Dosen

Xiao, Jian and Stephen Wilkins. 2015. The Effects of Lecturer Commitment on Student Perceptions of Teaching Quality and Student Satisfaction in 
Analis is Tingkat Kepuasan Mahasiswa Terhadap Kinerja Dosen Sekolah Tinggi Ilmu Ekonomi (STIE) di wilayah Kota Pekanbaru (Elida Gultom; Nurhayana)

Chinese Higher Education. Journal of

Higher Education Policy and

Management, 37. Page 98-110 